\title{
PROBLEMS OF HARMONIZATION ON THE POST-ESTABLISHMENT OF OMNIBUS LAW ON JOB CREATION
}

\author{
Henry Donald Lbn. Toruan \\ Researcher of Badan Penelitian dan Pengembangan Hukum dan Hak Asasi Manusia, \\ Kementerian Hukum dan Hak Asasi Manusia Republik Indonesia, Jakarta. \\ Corresponding author. Email: henrydonald.lt@gmail.com \\ Paper received on: 16-08-2021; Revised on: 01-11-2021; Approved to be published on: 16-11-2021; \\ DOI : http://dx.doi.org/10.30641/dejure.2021.V21.459-472
}

\begin{abstract}
The government has issued Law Number 11 Year 2020 concerning Job Creation (UUCK) on November 2, 2020. Through this law, around 1,200 articles in eighty laws are simplified into one law that regulates the provisions of the replaced laws. The model of simplifying regulations by combining various laws into a law is called the Omnibus Law. The establishment of the UUCK was a form of simplification of regulations related to the job creation process. The statement of the problem of this research is how to harmonize subordinate regulations into law, which was previously an implementing regulation from a law into a law. The research method used is normative juridical which is descriptive analysis. Law No. 12 Year 2011 as amended by Law No. 15 Year 2019 concerning the Establishment of Laws and Regulations states that harmonization was still in the draft stage. Therefore, no provisions govern the harmonization of regulations in force. If there are overlapped regulations both vertically and horizontally under the law, the settlement mechanism is done through the judiciary, namely the Supreme Court. This research concludes that the settlement of the disharmony regulation is resolved through executive review or analysis and evaluation.
\end{abstract}

Keywords: problems; harmonization and the job creation law

\section{INTRODUCTION}

The government has issued Law Number 11 Year 2020 concerning Job Creation (UUCK) on November 2, 2020. In the general explanation, it is stated that Indonesia still faces various obstacles in doing business, including for Cooperatives and Micro, Small and Medium Enterprises (MSMEs). In the explanation of UUCK, it is stated that currently, there is complexity and obesity in regulations where there are 4,451 Central Government Regulations and 15,965 Regional Government Regulations. Regulations and institutions are the main obstacles besides fiscal, infrastructure and human resource constraints. The regulation simplification model by combining various laws that regulate various things into one law is called the Omnibus Law. The establishment of the Omnibus Law model regulation is a legal breakthrough in resolving regulatory disharmony, especially related to the entry of foreign investment into Indonesia. This is because what has happened so far is that each ministry/agency has issued regulations that are often not in harmony with the regulations of other ministries.

UUCK was drafted as a method of simplifying regulations related to the job creation process. Through this law, about 1,200 articles that are stated in about eighty laws are simplified into one law. The drafting of Law Number 11 Year 2020 concerning Job Creation is considered important to overcome the problems that arise in the process of job creation in Indonesia, in the form of overlapping policies, excessive number of regulations, policy inefficiencies, as well as high sectoral ego and policy incoherence which have an impact on legal certainty in the process of job creation. ${ }^{1}$ However, it is necessary to issue implementing regulations as more detailed operational guidelines for implementing UUCK. A critical note issued by the Faculty of Law of UGM on Law Number 11 Year 2020 concerning Job Creation states that UUCK requires around 500 derivative rules. ${ }^{2}$ With this simplification of

\footnotetext{
Omnibus Law Cipta Lapangan Kerja Kementerian Koordinator Bidang Perekonomian Republik Indonesia, "Omnibus Law Cipta Lapangan Kerja," diakses 15 Agustus 2021, https://Dikti.Kemdikbud. Go.Id/Wp-Content/Uploads/2020/10/Booklet-UUCipta-Kerja.Pdf.

2 Fakultas Hukum Universitas Gadjah Mada, Kertas Kebijakan Catatan Kritis Terhadap UU No 11 Tahun 2020 Tentang Cipta Kerja, Edisi 2, Fakultas Hukum Universitas Gadjah Mada Tahun 2020, 4 (Jogyakarta,
} 
regulations, it is hoped that it will attract foreign investment to Indonesia in order to increase economic growth and create job opportunities.

Currently, the government has completed 51 Implementing Regulations of Law Number 11 Year 2020 concerning Job Creation (Job Creation Law). The implementing regulations that were first completed were two Government Regulations (PP) related to Investment Management Institutions (LPI), namely Government Regulation Number 73 Year 2020 concerning Investment Management Institutions (LPI) and Government Regulation Number 74 Year 2020 concerning Initial Capital of Investment Management Institutions.

Furthermore, 49 implementing regulations consisting of 45 Government Regulations and 4 Presidential Regulations (Perpres) were drafted by 20 ministries/agencies (K/L) according to their respective clusters. In terms of substance, the implementing regulations are grouped into 11 regulatory clusters. First, namely Licensing and Sectoral Business Activities as many as 15 Government Regulations. Second, namely Cooperatives and MSMEs and Village-Owned Enterprises (BUMDes) as many as 4 Government Regulations. Third, namely Investment as many as 5 Government Regulations and 1 Presidential Regulation. Fourth, namely Manpower as many as 4 Government Regulations. Fifth, Fiscal Facilities as many as 3 Government Regulations. Sixth, namely Spatial Planning as many as 3 Government Regulations and 1 Presidential Regulation. Seventh, namely Land and Land Rights as many as 5 Government Regulations. Eighth, namely Environment as many as 1 Government Regulation. Ninth, namely Construction and Housing as many as 5 Government Regulations and 1 Presidential Regulation. Tenth, namely Economic Zones as many as 2 Government Regulations. Eleventh, namely Government Goods and Services as many as 1 Presidential Regulation. ${ }^{3}$

In order to support the entry of investment and the creation of job opportunities, various changes have been made to around 80 (eighty) laws that

2020) < Kertas Kebijakan Catatan Kritis Terhadap UU No 11 Tahun 2020 tentang Cipta Kerja, Edisi 2/ 5 November 2020, Fakultas Hukum Universitas Gadjah Mada Tahun 2020, 4.

3 Kementerian Koordinator Bidang Perekonomian Republik Indonesia, "Omnibus Law Cipta Lapangan Kerja." have been included in the UUCK. The laws that have been included previously had a number of implementing regulations at the central level and were also used as a reference in the establishment of regional regulations. The problem is that these laws and regulations have not been harmonized with the 80 laws that were changed vertically with the UUCK. Even these implementing regulations horizontally with equivalent regulations also need to be harmonized. This is because, what has happened so far among implementing regulations, there are often overlapping arrangements due to the sectoral ego of each ministry/agency. This is a problem in our legislation, which does not have legal rules on how to harmonize and synchronize the existing applicable laws and regulations.

The harmonization of laws and regulations under the laws that are included in the UUCK is still an unsolvable matter even though there is already a Draft Government Regulation (RPP) on the Harmonization and Synchronization of Laws and Regulations under the Law as mandated by Article 181 of the UUCK to harmonize and synchronize any law and regulation under the Law that contradicts the provisions of the UUCK, higher laws and regulations, or court contradicts decisions (the Constitutional the Court and Supreme Court). However, the draft RPP has drawn criticism and rejection because harmonization and synchronization in the form of review of the applicable laws and regulations are not recognized in the establishment of laws and regulations in Indonesia. Law No. 15 Year 2019 concerning Amendments to Law Number 12 Year 2011 concerning the Establishment of Laws and Regulations (UUP3) does not regulate the examination of regulations under laws that contradict the higher regulations. Furthermore, in UUP3 it is stated that in the event that a Law and Regulation under a Law is alleged to contradict the Law, the review shall be carried out by the Supreme Court (Article 9 paragraph 2). The review at the Supreme Court is also not a solution because what is being harmonized involves hundreds of laws and regulations. The trial process at the Supreme Court takes a long time to complete the review of one regulation. Then, there is a limited number of Supreme Court justices who handle review lawsuits. Therefore, review lawsuits at the Supreme Court cannot be a solution to resolve hundreds or even thousands of disharmony laws 
and regulations. The statement of the problem in this paper is how to harmonize the laws and regulations under the law which were originally the implementing regulations of the laws that were merged into the UUCK.

\section{RESEARCHMETHOD}

The type of research in this paper is normative legal research, namely legal library research. ${ }^{4}$ Legal research is a process to find the legal rule, legal principles and legal doctrines in order to answer the legal issues faced. ${ }^{5}$ Legal research is carried out to produce new arguments, theories or concepts as prescriptions in solving problems at hand. ${ }^{6}$ Legal research is conducted to produce new arguments, theories or concepts as prescriptions in solving problems at hand. ${ }^{7}$ This research is descriptive analysis with a conceptual approach. This approach was taken because there is no legal regulation for the problem at hand. ${ }^{8}$ The research sources used in this paper are primary legal materials and secondary legal materials. Primary legal materials consist of legislation, official records or minutes in the making of legislation and judges' decisions. Secondary legal materials are all publications on law that are not official documents such as textbooks, legal journals, and comments on court decisions. ${ }^{9}$ In addition, data collection was carried out by discussing with experts in the field of state administration/legislation from various law faculties through zoom meetings. All data collected was processed and analyzed in depth by looking at various data and facts as well as legal needs that can support simplification of disharmony law so that conclusions and suggestions can be drawn for legal improvement in order to harmonize legislation.

\section{DISCUSSION AND ANALYSIS}

\section{Thorough Examination}

The establishment of laws and regulations in Indonesia by taking over other rules has actually

\footnotetext{
4 Sri Soerjono \& Mamuji Soekanto, Penelitian Hukum Normatif: Suatu Tinjauan Singkat, 5th ed. (Jakarta: Raja Grafindo Persada, 2011), 23.

5 Peter Mahmud Marzuki, Penelitian Hukum, 7th ed. (Jakarta: Kencana Prenada Media Group, 2011), 27.

6 Ibid.

Ibid.

8 Ibid.

9 Ibid.
}

been carried out for a long time, such as the enactment of colonial regulations, the codification of laws in the Civil Code and the transplantation of foreign laws into national law. Tri Budiyono states that Transplantation is the taking over of legal rules, legal teachings (doctrine), structures, or legal institutions from one legal system to another or from one jurisdiction to another. ${ }^{10}$ The term transplantation is one of the models in the context of taking over the rule of foreign law as a whole into national law. Another takeover model is what is known as the Omnibus Law where a regulation contains various things in one provision, either of the same type or of another type. The adoption of foreign legal models into national law is intended to make changes to the law because the laws that specifically regulate the economy are numerous and disharmony with one another. This disharmony regulation is an obstacle to the entry of investment into Indonesia from developed countries. In fact, investment is necessary for economic growth and job creation for the community.

The background to the emergence of the idea of omnibus law is the complexity of investing in Indonesia. This complexity arises in several ways, namely licensing, taxation, land acquisition and other aspects related to investment. The omnibus law was initiated by the government to simplify the existing laws and regulations in Indonesia which leads to smooth investment in Indonesia. ${ }^{11}$ Omnibus law is a law whose substance is to revise and/or to revoke many laws. This concept developed in common law countries with Anglo Saxon legal system such as the United States, Belgium, England and Canada. The concept of omnibus law offers to fix problems caused by too many regulations (over regulation) and overlapping. If the problem is solved in the usual way, this will take quite a long time and cost a lot of money. Moreover, the process of designing and formulating laws and regulations often creates deadlock or is not in accordance with interests. ${ }^{12}$ The formulation of laws and regulations adopted by Indonesia with its civil law system is to put

1o Tri Budiyono, Transplantasi Hukum Harmonisasi Dan Potensi Benturan (Salatiga: Griya Media, 2009), hlm. 11

" Adhi Setyo Prabowo dkk, "Penerapan Omnibus Law Dalam Upaya Reformasi Regulasi," Pamator 13 No. 1 (2020):3

12 Antoni Putra, "Penerapan Omnibus Law Dalam Upaya Reformasi Regulasi," Legislasi Indonesia 17 No.1 (2020): 2. 
forward a long process as regulated in the Law of Establishment of Legislation in casu Law Number 12 Year 2011 in conjunction with Law Number 15 Year 2019 concerning the Establishment of Laws and Regulations. This process is carried out to ensure and guarantee legal certainty of the content materials of the establishment of laws and regulations that are formulated. ${ }^{13}$

The concept of omnibus law can actually be a solution to simplify too many regulations, as Indonesia is currently experiencing. As revealed by Bappenas, from 2000 to 2015, the central government has issued 12,471 regulations, with the ministries being the largest producer with 8,311 regulations. The next most type of regulation is government regulation with 2,446 regulations. Meanwhile, regulatory products issued by local governments are dominated by district/city regulations with a total of 25,575 regulations, followed by provincial regulations with 3,177 regulations. ${ }^{14}$ Moreover, the provisions of the establishment of law as regulated in UUP3 only discuss similar law materials and it is not possible to discuss various legal materials in one law. Of course, a legal breakthrough must be made to overcome this problem by using a method called the Omnibus law.

What is meant by omnibus law? In the United States Duhaime Legal Dictionary, "Omnibus Bill” is defined as: "A draft law before a legislature which contains more than one substantive matter, or several minor matters which have been combined into one bill, ostensibly for the sake of convenience". ${ }^{15}$ Conceptually, the technique of establishment of laws using the "omnibus law" method is applied to change some or even many laws that contain various policy materials that are interrelated with one another. With the omnibus law technique, it is hoped that the various provisions contained in several different laws can be harmoniously integrated into issues of the same domain with one law that guarantees the improvement of the national legal system. ${ }^{16}$

13 I Putu Eka Cakra dan Aditya Yuli Sulistyawan, "Kompabilitas Penerapan Konsep Omnibus Law Dalam Sistem Hukum Indonesia," Crepido 02 No.02 (2020):60.

14 Ibid.

${ }^{15}$ Jimly Asshiddiqie, Omnibus Law Dan Penerapannya Di Indonesia (Jakarta: Konstitusi Press, 2020), 3.

16 Ahmad Redi \& Ibnu Sina Chandranegara, Omnibus Law, Diskursus Penerapannya Dalam Sistem
Jimly Asshiddiqie states that by using the omnibus technique, the first step to take is to review and evaluate all statutory legal documents, both horizontally and related to each other, namely those relating to materials that regulate the same things contained in the different laws; or vertically, namely between regulations with different hierarchical levels, starting from the highest to the lowest. The duties of evaluators and reviewers of this kind are what have been called legal auditors. ${ }^{17}$ Furthermore, he states that in addition to Omnibus law, there is also a definition of Omnibus law Rules or Omnibus Regulation. Although the definition of omnibus law and regulation has received less attention among academicians and practitioners, the definition of an omnibus bill can also be developed in the context of laws and regulations under the law. Even at the provincial, district and city levels of government. Regional regulations (Perda) can also be seen as legal products, like laws too, but are local in nature and only apply in their respective regions. At the district and city levels, the definition of the Omnibus Regional Regulation can also be known. ${ }^{18}$

In relation to this statement, it is necessary to conduct a thorough examination of the laws and regulations that are derivatives of the eighty laws that were included in the UUCK, both vertically and horizontally in order to minimize overlapping regulations. A thorough examination is nothing new. In the capital market, this is known as due diligence, namely to examine the overall finances of a company that will go public. The same thing can be applied in a thorough examination of inharmonious laws and regulations. Of course, the examination in question is a big job because it requires the expertise of the audit team or legal auditor. However, because the legal auditor is not found as a functional position in the ministries/ agencies, the examination can be performed by a legal researcher or legal analyst who is a functional position in the ministries/agencies. The results of a thorough examination carried out will be able to classify the form and type as well as content material of the inharmonious regulations. Recommendations fromthis thoroughexamination

\footnotetext{
Perundang Undangan Nasional (Depok: Rajawali Pers, 2020), 3 .

18 Asshiddiqie, Omnibus Law Dan Penerapannya Di Indonesia, 37.
}

${ }_{17}$ Ibid, 37 . 
can be in the form of revocation, improvement or establishment of joint regulations. Examination or review conducted by the government so far is known as executive review or analysis and evaluation. However, the examination conducted at BPHN only focuses on one law that will be analyzed and evaluated. There has never been a thorough examination of the laws and regulations under disharmony laws.

\section{Harmonization of Legislation}

In general, the law as accepted and implemented in countries in the world belongs to the category of modern law. This modernity has the following characteristics: 1 . Having a written form; 2 . The law applies to the entire territory of the country; 3. The law is an instrument that is used consciously to realize the political decisions of its people. ${ }^{19}$ The construction of modern law cannot be separated from the mainstream of modernity, namely positivism. According to Satjipto Rahardjo, the influence of positivism on law began to be felt in the nineteenth century along with the presence of modern law which organizes society rationally. Since the nineteenth century, law has become a real institution, whether in the substance, methodology and administration. In terms of substance, the law relies on regulations that it produces itself, namely legislated rules. There are no other regulations in society, except those produced by legal institutions. In this case, a special agency was established to make regulations. This change triggered a large number of regulations made specifically and deliberately (purposeful) by the (modern) legal machine, which had never been experienced before..$^{20}$ The influence of positivism is very much felt in our constitutional life where all aspects of life must be regulated in laws and regulations. Each ministry/ agency and local government seeks to make regulations related to its authority. However, these regulations often collide with other regulations both vertically and horizontally, causing legal uncertainty in society. Therefore, it is necessary to make efforts to harmonize laws and regulations, especially those related to UUCK so that all

19 Satjipto Rahardjo, Ilmu Hukum, V. (Bandung: Citra Aditya Bakti, 200o), 213-214.

20 Satjipto Rahardjo, dkk, Refleksi Dan Rekonstruksi Ilmu Hukum Indonesia, ed. Awaluddin Marwan Esmi Warassih, Suteki, 1st ed. (Yogyakarta: Thafa Media, 2012), 147 . regulatory products from the highest to the lowest are in harmony.

The term harmonization is actually a terminology in music science to show the harmony and beauty of the tones. The term harmonization becomes relevant to be used in the legal field, considering that the law also requires harmony so that all levels of society can feel the benefits. ${ }^{21}$ In the Great Dictionary of the Indonesian Language, harmonisasi (harmonization) comes from the word harmoni (harmony), and it means an effort to seek harmony. ${ }^{22}$ Rudolf Stammler put forward a concept of the function of law, that the purpose or function of law is the harmonization of various purposes, goals and interests between an individual and another individual and between an individual and society. According to Stammler, "A just law aims at harmonizing individual purposes with that of society". ${ }^{23}$ Therefore, fair law, in this case laws and regulations, aims to harmonize the goals of the individual with the goals of society.

Harmonization is important to do because we adopt the teaching of the tiered theory of Hans Kelsen with the Stufenbau Theory, which teaches that lower regulations should not conflict with higher regulations. Hans Kelsen put forward the stufenbau theory (stufenbau des rechts theorie) in his book which was translated into English under the title General Theory of Law and State by Anders Wedberg that "The creation of one norm - the lower one - is determined by another - the higher - the creation of which is determined by a still higher norm, and that this regresses is terminated by a highest, the basic norm which, being the supreme reason of validity of the whole legal order, constitutes in unity.” According to Hans Kelsen, the basic norm (grundnorm) which is the highest norm in the norm system is no longer formed by a higher norm, but the grundnorm is determined in advance by the community as the basic norm which is the hanger for the norms under it so that a basic norm is said to be presupposed. ${ }^{24}$ In his theory, Hans Kelsen argues that

${ }^{21}$ Kusnu Goesniadhie, Harmonisasi Sistem Hukum : Mewujudkan Tata Pemerintahan Yang Baik (Malang: Nasa Media, 2010), 13.

22 Dahlan Barry and Et.al, Kamus Modern Bahasa Indonesia (Jogyakarta: Arkola, 1995), 12.

${ }^{23}$ Goesniadhie, Harmonisasi Sistem Hukum: Mewujudkan Tata Pemerintahan Yang Baik, 2.

24 Redi and Ahmad, Hukum Pembentukan Peraturan Perundang-Undangan (Jakarta: Sinar Grafika, 2018), 
legal norms are tiered and layered in a hierarchy (organization). This means that a lower norm applies, originates, and is based on a higher norm; a higher norm applies, originates, and is based on a higher norm until it reaches a norm that cannot be traced further and is hypothetical and fictitious, namely the basic norm (grundnorm). ${ }^{25}$

One of the figures who developed this theory was a student of Hans Kelsen, namely Hans Nawiasky. Nawiasky's theory is called theorie van stufenubau der rehtsardnung. The structure of norms according to the theory is:

1. Fundamental norms of the state (Staatsfundamentalnorm);

2. Thebasicrulesofthestate(staatsgrundgesetz);

3. Formal law (formell gesetz); and

4. Implementing regulations and autonomous regulations (verordnung en autonome satzung). ${ }^{26}$

Based on Nawiasky's theory, A. Hamid S. Attamimi compares it with Kelsen's theory and applies it to the structure of the legal system in Indonesia. Attamimi shows the hierarchical structure of the Indonesian legal system using Nawiasky's theory. Based on this theory, the structure of the Indonesian legal system is:

1. Staatsfundamentalnorm: Pancasila (Preamble to the 1945 Constitution).

2. Staatsgrundgesetz: Body of the 1945 Constitution, Decree of the People's ConsultativeAssembly, andthe Constitutional Convention.

3. Formell Gesetz: Laws

4. Verordnung en autonome Satzung: Hierarchically starting from Government Regulations to Regent or Mayor Decrees. ${ }^{27}$

The theory of Hans Kelsen and Nawiasky is what inspired the formation of the order of legislation regulated in Law No. 10 Year 2004 as amended in Law No. 12 Year 2011 concerning the Establishment of Laws and Regulations where in Article 7 paragraph (1) it is stated that the Types and hierarchy of Laws and Regulations consist of:

a. the 1945 Constitution of the Republic of Indonesia;

$$
41 .
$$$$
25 \text { Ibid. }
$$$$
26 \text { Ibid. }
$$$$
27 \text { Ibid. }
$$

b. Decree of the People's Consultative Assembly;

c. Laws/Government Regulations in Lieu of Laws;

d. Government Regulations;

e. Presidential Regulation;

f. Provincial Regional Regulations; and

g. Regency/City Regional Regulations.

Borrowing Hans Kelsen's term, it means that the 1945 Constitution is the Grundnorm or the highest basic norm, which is the legal source for the formation of regulations under it. So that the material content of Laws must be sourced from the 1945 Constitution and Government Regulations contain material to implement the Laws. The material contents of Presidential Regulations contain material ordered by the Laws, and so on until the lower-level regulations as specified in UUP3. In the legal system in force in Indonesia, the need for harmonization between the lowest regulation and the regulations above it or with regulations of the same level is always prioritized. At the drafting stage, each draft regulation is required to be harmonized first so that when it is ratified into laws and regulations it will create legal certainty and does not conflict with other regulations.

Harmonization serves as an effort to prevent and countermeasures against legal disharmony. At the same time, harmonization is intended as an effort of supervision to prevent the possibility of a draft regulation containing legal defects from the initiating agency. In the harmonization process, there are two important aspects that are harmonized, namely: aspect of the conception of the material content of laws and regulations and technical aspect of the drafting of laws and regulations. Aspect of the conception of material content includes the harmonization with higher legislation, horizontal harmonization, and harmonization with legislation. Aspect of the conception of material content includes harmonization with higher laws and regulations, horizontal harmonization, harmonization with the interests of the community, harmonization with the principles of human rights, and harmonization with the principles of formation and principle of the material content of laws and regulations. The technical harmonization of the drafting includes harmonization of the framework, format, 
systematics, delegation of authority and several other technical aspects. ${ }^{28}$

The issuance of UUCK using the omnibus law model when viewed from a legal perspective has not solved the problem. This is because the 80 laws that were included in the UUCK previously had various implementing regulations, including government regulations, presidential regulations, ministerial/agency regulations, provincial and district/city regulations. The problem is that before being issued, the laws and regulations have gone through the stages of a harmonization mechanism. However, because the parent law was included in the UUCK and various changes have been made, automatically the laws and regulations under it are in conflict with the UUCK. If referring to UUP3 there are no provisions governing the harmonization of existing applicable laws and regulations. Harmonization is always carried out while still in the stage of draft regulation. The provisions governing the harmonization, unanimity, and consolidation of the conception of Draft Laws, Draft Government Regulations, Draft Presidential Regulations and Draft Regional Regulations are regulated in UUP3, namely: Article 46 paragraph 2, Article 47 paragraph 3, Article 54 paragraph 2, Article 55 paragraph 2 and Article 58 paragraphs 1 and 2.

Although there are provisions that require harmonization while still at the draft stage, in practice there are still many laws and regulations that are not harmonious. One of the obstacles to harmonization is the strong sectoral ego of the ministries/agencies. This is because government affairs often intersect with one another, so that when discussing and harmonizing regulations certain ministries/agencies deem to have more authoritative. Meanwhile, at the local government level, there is a strong desire to produce regulations aimed at increasing local revenue (PAD) which does not pay attention to other higher regulations. Under these conditions, there is often a conflict of regulations both vertically and horizontally which causes disharmony and creates legal uncertainty. If such a conflict occurs, then according to UUP3 in Article 9 it is stated that if the Law is alleged

28 Khairul Fahmi, Menggagas Arah Kebijakan Reformasi Regulasi Di Indonesia Prosiding Forum Akademik Kebijakan Reformasi Regulasi 2019, 1st ed. (Jakarta: Yayasan Studi Hukum dan Kebijakan Indonesia (YSHK), 2019), 161-162. to be in conflict with the 1945 Constitution, the review will be carried out by the Constitutional Court (paragraph 1). Likewise with laws and regulations under a law that is alleged to be in conflict with the law, where the review is carried out by the Supreme Court (2). With reference to the provisions of the UUP3 above, it is known that if there are laws and regulations that conflict with the regulations above them, then the settlement method must be through a judicial institution, namely the Constitutional Court for the law level and the Supreme Court for regulations under the law.

The Minister of Law and Human Rights seeks to overcome the issue of disharmony of conflicting regulations outside the court by means of mediation through Regulation of the Minister of Law and Human Rights Number 2 Year 2019 concerning Settlement of Disharmony of Laws and Regulations through Mediation. In the provisions of Article 2 it is stated that the Types of Laws and Regulations that are examined through Mediation are:

a. Ministerial regulation;

b. Non-ministerial Government Agency Regulation;

c. Regulations from Non-structural Agency; and

d. Laws and Regulations in regions.

The establishment of the Regulation of the Minister of Law and Human Rights in overcoming disharmony of regulations at the ministry/ agency level and regional regulations should be appreciated. However, UUP3 does not regulate the settlement of overlapping cases through nonjudicial method, therefore there is no delegation of regulation establishment in the form of mediation.

\section{Draft Government Regulation on Harmonization and Synchronization and Implementation Constraints}

Implementation is an activity carried out by planning and referring to certain rules to achieve the objectives of an activity. In essence, implementation can be done if there is already a plan or concept of the event to be carried out. The results of the implementation of the plan are expected to achieve the goals to the maximum and not disappoint those who have been waiting for it. The purpose of implementation is to implement and realize the plans that have been prepared 
into a tangible form. This is because in making a plan, the objectives to be achieved are also listed. Therefore, implementation can practically be said as a way to achieve the related goals. ${ }^{29}$ The idea of harmonizing laws and regulations under the laws that are in conflict with the laws has been stated in Article 181 of the Job Creation Law. The provisions of Article 181 mandate the establishment of implementing regulations, which are currently in the form of a Draft Government Regulation on Harmonization and Synchronization of Laws and Regulations under the Law, which is expected to be implemented to conduct an examination of the laws and regulations under the law that are contrary to the law or Court Decisions. The implementation of harmonization will be coordinated by the Minister of Law and Human Rights. Meanwhile, for Regional Regulations and Regional Head Regulations, the implementation of harmonization will be coordinated jointly between the Minister of Law and Human Rights and the Ministry of Home Affairs.

In the Draft Government Regulation, it is stated that the Minister of Law and Human Rights will establish an ad hoc Working Group for the implementation of Harmonization and Synchronization of the laws and regulations with membership from various elements, namely the Ministry ofLaw,relatedMinistries, experts,drafters of Laws and Regulations, professional circles, and practitioners/business actors. Implementation of Harmonization and Synchronization can be done if there is an application submitted by: a. Indonesian citizen or legal entity, b. ministries/agencies and c. regional government. In addition to application, Harmonization and Synchronization can also be carried out based on the results of monitoring and review conducted by ministry/agency.

The Working Group has the task of examining, analyzing, and deciding on the content materials of the laws and regulations that are considered contradictory. If the result of the Working Group's decision is that the regulation which is examined is in conflict with higher Laws and Regulations or in conflict with Court Decisions, the Working Group will submit a proposed recommendation to the Minister of Law and Human Rights. Furthermore, the Minister of Law and Human Rights provides recommendations to

\footnotetext{
${ }_{29}$ Mutaya Saroh, "Apa Itu Implementasi? Tujuan Dan
} Contoh Penerapannya," Suara.Com, n.d. the ministries/agencies to amend or revoke the laws and regulations under the Law. In terms of implementing the recommendations, the Minister of Law and Human Rights submits the results of the Harmonization and Synchronization to the President where the President can assign the heads of the relevant ministries/agencies to follow up on the recommendations.

The Working Group can only be formed if there is an application for Harmonization and Synchronization submitted by individuals or legal entities, ministries/agencies and regional governments. The reason for submitting the application is because the individual or legal entity is disadvantaged or the duties and functions of the ministry or regional government are hampered. In addition, the application for Harmonization and Synchronization can also be carried out based on the results of monitoring and review of laws and regulations carried out by ministries/agencies. The concept of this Draft Government Regulation is very inappropriate, if it is intended to amend laws and regulations under laws that are contrary to the UUCK. This is because a number of laws that have been included in the UUCK have undergone substantial changes.

The concept of examination in the Draft Government Regulation on Harmonization and Synchronization has received various responses from legal expert academicians who are resource persons in the research conducted by the author. The research team on the Readiness of Implementation of Harmonization and Synchronization of Legislation After the Establishment of the Omnibus Law Regulation in Law Number 11 Year 2020 concerning Job Creation (Research and Development Board for Law and Human Rights) conducted a series of interviews with academicians who are experts in legislation, namely: Wicipto Setiadi, Bayu Dwi Anggoro, Fitriani Ahlan Sjarif and Jamin Ginting, which was held on Tuesday, July 62021 at 13.00 - 15.00 WIB via the Zoom Meeting Application.

Wicipto Setiadi states that so far there has been no Working Group in the harmonization and synchronization process, but it is done through directorate such as harmonization I, II, and so on which are inherent in the directorate's task and function by involving various ministries and experts. The Draft Government Regulation on Harmonization and Synchronization seems to 
be unfocused and too broad in scope because it regulates the criteria for the harmonization and synchronization applicant, which so far only applies to judicial harmonization and synchronization. Then, Bayu Dwi Anggoro states that regarding the provisions of the Draft Government Regulation regarding the harmonization and synchronization process where only through the complaint process, it is feared that it will remove the role of the relevant agencies in monitoring the implementation of the law. In addition, the application provisions do not constitute a mandate from Article 181 of the Job Creation Law.

Harmonization and synchronization through the complaint mechanism would actually be contrary to the duties and functions of preventive community protection owned by the government. Therefore, there should be no provisions regarding complaint in the Draft Government Regulation in the implementation of harmonization and synchronization. Fitriani Ahlan Sjarif expressly disagrees with the concept initiated in the Draft Government Regulation on Harmonization and Synchronization because the concept must be carried out before ratification or promulgation of laws and regulations. Meanwhile, Jamin Ginting states that there is no procedural law mechanism used in examinations at the Working Group Level through a trial panel whose membership consisted of the relevant ministries/agencies, experts, drafters of laws and regulations, professionals, and practitioners. These provisions should take into account the Procedural Law, Form of Decision, Examination Period, and Legal Efforts.

The Working Group's ad hoc examination model initiated in the Draft Government Regulation on Harmonization and Synchronization is a non-judicial trial, which is established at the central and regional levels. The Working Group is only established if there is an application from parties whose interests have been harmed, be it the community or legal entities, ministries/agencies and regional governments. The concept of Working Group examination will be difficult to implement because there is no examination mechanism, grace period and trial procedure until a decision is issued in the form of a recommendation. Then, no alternative is given for the applicant who does not accept the results of the recommendation decision.

Although there has been a simplification of regulations at the statutory level in the omnibus law of UUCK, there are no appropriate regulations in an effort to harmonize and synchronize laws and regulations that are disharmony under the law. Therefore, the government's desire to raise the rating of ease of doing business in order to attract investment will be difficult to achieve. This is because the examination is ad hoc in the concept of the Draft Government Regulation on Harmonization and Synchronization, is only based on application and will not be able to immediately resolve hundreds of disharmony regulations that hamper the economy. Law should be able to play a role in improving the economy and not be an obstacle to economic progress.

\section{Testing Method}

The theory of testing (toetsing), according to Jimly Asshiddiqie, is distinguished between materiele toetsing and formele toetsing. The two forms of testing are distinguished by the terms law establishment and law material. If the testing of the law is carried out on the material, then this test is called a judicial review which can result in the revocation of some of the material of the law in question, whereas if the testing of the law is carried out on the process of its establishment, then such a testing is called a formal review. This formal review is carried out to assess whether a legislative product is established through the procedures as determined/regulated in the applicable laws and regulations or not. ${ }^{30}$

Provisions of judicial review of laws and regulations under the law consist of:

a. Article 24 A paragraph (1) of the 1945 Constitution of the Republic of Indonesia;

b. Article20 paragraph(2) letterband paragraph (3) of Law No. 48 Year 2009 concerning Judicial Power (previously Article 11 paragraph (2) letter b and paragraph (3) of Law No. 4 Year 2004 concerning Judicial Power);

c. Article 31 and Article 31 A of Law No. 14 Year 1985 concerning the Supreme Court, as amended two times, lastly by Law No. 3 Year 2009;

d. Article 145 paragraph (5) and paragraph (6) of Law No. 32 Year 2004 concerning Regional Government;

3o Bayu Dwi Anggoro, Perkembangan Pembentukan Undang-Undang Di Indonesia, ed. Rita Triana Budiarti, 1st ed. (Jakarta: Konstitusi Press, 2014), 29-30. 
e. Article 9 paragraph (2) of Law No. 12 Year 2011 concerning the Establishment of Laws and Regulations. ${ }^{31}$

The provision of Article 24 A paragraph (1) of the 1945 Constitution of the Republic of Indonesia states: "The Supreme Court has the authority to adjudicate at the level of cassation, to review laws and regulations under the law against the law and have other authority granted by law." The provision of Article 20 paragraph (2) letter b of Law No. 48 Year 2009 (previously Article 11 paragraph (2) letter b of Law No. 4 Year 2004) essentially states that the Supreme Court has the authority to review laws and regulations under the law against the law. The provision of Article 20 paragraph (3) of Law No. 48 Year 2009 (previously Article 11 paragraph (3) of Law No. 4 Year 2004) essentially states that a statement that the laws and regulations are not valid as a result of the review as referred to in paragraph (2) letter b can be taken both in review in the cassation level and based on a direct application to the Supreme Court. ${ }^{32}$

Therefore, testing laws and regulations that are contrary to higher regulations in the practice of submitting examinations is through the judiciary, which is known as judicial review. Such examination can only be carried out by the Supreme Court. If there are parties who object, thus submit an application to the said judiciary. Of course, the examination carried out by the Supreme Court judges only examines based on the application submitted, namely case by case. The problem is, the testing arrangements mentioned above do not regulate how to test or examine the establishment of regulations with an omnibus law model such as the UUCK which has drawn around 80 laws into it.

Therefore, the examination model through testing in the Supreme Court towards the laws and regulations under the law that was included in the UUCK is not a solution in solving the problem of overlapping regulations. This is because the number of examinations of disharmony laws and regulations is quite large. In the general explanation of UUCK it is stated that "Currently there are complexity and obesity of regulations, where there are 4,451 Central Government Regulations

\footnotetext{
${ }^{31}$ Sukardi, Pengawasan Dan Pembatalan Peraturan Daerah, ed. Ahmad Fikri Hadin, ist ed. (Bantul, Yogyakarta: Genta, 2016), 68-69.

32 Ibid.
}

and 15,965 Regional Government Regulations. Regulations and institutions are the main obstacles in addition to fiscal, infrastructure and human resources constraints. To create a conducive business climate, of course, legal breakthroughs must be made in resolving the disharmony of the laws and regulations in Indonesia by simplifying the various laws into one law, which is called the Omnibus Law."

Therefore, the simplification according to the UUCK explanation is only at the level of the law; it does not reach laws and regulations under it. Meanwhile, the testing in the Supreme Court is only case by case according to the application submitted by the objecting or disadvantaged party. Whereas the completion of a number of laws and regulations as described in the UUCK above cannot wait for a party to submit an application to the Supreme Court on a case-by-case basis, but a thorough examination must be carried out in order to create legal certainty. This is a problem that cannot be solved yet: how to harmonize the derivatives of the simplified laws and regulations so that they do not conflict with the UUCK.

The government has made the concept of Draft Government Regulation on the Harmonization and Synchronization of Laws and Regulations under the Law (Draft Government Regulation on Harmonization and Synchronization) as mandated by Article 181 of the UUCK, namely to harmonize and synchronize all laws and regulations under the law which are contrary to the provisions of the UUCK and higher laws and regulations. In the Draft Government Regulation on Harmonization and Synchronization, testing is carried out by a Working Group consisting of various elements from academicians, practitioners, ministries and drafters of regulations. The Working Group will examine, analyze, and decide on the content materials of the laws and regulation sunder the Law.

In the concept of the Draft Government RegulationonHarmonization andSynchronization, the examination conducted by the Working Group is a judicial review. Whereas the Working Group's duties only include the stage of providing recommendations; they do not include the revocation of the regulations applied for review. The next step is to submit recommendations to the Minister of Law and Human Rights and submit them to the relevant ministries. If the 
relevant ministries do not follow up on the recommendations, the Minister of Law and Human Rights shall submit the recommendations to the President and then the President orders the relevant ministries to revoke the regulations. This process is quite long and will take a long time so it is not efficient. According to the theory of testing, the examination by the Working Group is clearly not categorized as a judicial review because it cannot revoke the contents of laws and regulations applied for review. The concept of the Draft Government Regulation on Harmonization and Synchronization clearly contradicts the judicial review which is the domain of the Supreme Court's authority as regulated by a number of laws and regulations above.

The weakness of the examination pursuant the concept of Draft Government Regulation on Harmonization and Synchronization is that the examination does not explain the time limit and the examination procedures. In fact, the time limit and procedures for the examination are important in the performance of the tasks of the Working Group. Then, there is no provision regarding refusal if during the examination it is not proven that the applied regulation contradicts the regulations above it. The Draft Government Regulation does not regulate the mechanism if the applicant, either individual or legal entity, as well as ministry/ agency and local government does not accept the recommendations. In addition, by opening the opportunity to submit applications for testing laws for individuals and legal entities, this will have the potential to accumulate applications. Do all applications have to be examined according to the rules in court which may not reject applications submitted by parties? If the application submitted does not have a clear timeline, it is possible that the examination of the application will be protracted.

Therefore, in our opinion, the examination model in the concept of Draft Government Regulation on Harmonization and Synchronization in examining laws and regulations under the law is unable to comprehensively resolve conflicting laws. This is because the examination is only based on an application and is not based on a regulatory function that can provide legal certainty to encourage economic growth. Therefore, to resolve laws and regulations that conflict with the regulations above them, the concept of Draft Government Regulation on Harmonization and
Synchronization needs to be revised so that it does not use a semi-judicial model, but uses an analysis and evaluation model (executive review) carried out by each ministry/agency and regional government. The implementation of these analysis and evaluation activities is carried out by a team as specified in the Draft Government Regulation on Harmonization and Synchronization. So that the results of the analysis and evaluation activities can produce good regulations. Of course, the revised concept of the Draft Government Regulations must regulate the use of a methodological approach in conducting examination. In addition, there must be an institution that specifically monitors the implementation of the analysis and evaluation activities. So far, this task has been carried out by the National Law Development Agency. However, because there is no strong legal basis, the results of the analysis and evaluation are only for input materials without any coercive power.

There are various methodologies in harmonizing and synchronizing laws and regulations based on analysis and evaluation. Prof. Dr. Ida Bagus Rahmadi Supancana conveyed several views on performing regulation reform in Indonesia using a regulatory analysis model approach. From a number of models discussed, there are three interrelated models that can be used as references, namely: Regulatory Impact Analysis (RIA), Cost Benefit Analysis (CBA) and Cost Effective Analysis (CEA). According to Prof. Ida Bagus Rahmadi Supancana, RIAis a tool to analyze regulations through an analytical and systematic approach to regulatory problems that includes a range of means and techniques aimed at assessing the impact of regulations. RIA is also a structured way to communicate the results to decision makers and to the public. Then, he mentioned that RIA can be used to assist policy and regulation drafters in reducing the risk of regulation failure as well as risks that are unexpected consequences related to the implementation of a new regulation. In addition, another benefit that can be offered is to improve the quality of regulation, as long as it is implemented as a decision-support tool, not done partially, and has gone through a complete cost and benefit analysis process. ${ }^{33}$

33 Ida Bagus Rahmadi Supancana, Sebuah Gagasan Tentang Grand Design Reformasi Regulasi Indonesia (Jakarta: Universitas Katolik Indonesia-Atma Jaya, 2017), 44-45. 
Meanwhile, CBA according to Prof. Dr. Ida Bagus Rahmadi Supancana is an analysis method that measures and compares all benefits that will be obtained, as well as the costs/burdens/losses/ consequences that must be borne by all parties affected by a particular policy or regulation along with the available alternatives to assist the decision-making process. ${ }^{34}$ Furthermore, CBA is used to assess and decide whether a policy or regulation is feasible and possible to be carried out/implemented by taking into account and considering all benefits that will be obtained, as well as the costs/burdens that will be borne (benefits compared to costs). Meanwhile, CEA is used to determine the best, the most appropriate, effective and efficient option (can achieve a certain goal with the minimum cost) from various options/alternatives for solving existing problems (cost compared to objective/outcome-QALYS). QALYS (quality adjusted life years) is an increase in the quality and quantity of a person's life with an intervention (used for measuring/assessing benefits in the health sector). ${ }^{35}$

CBA has a relation with CEA, because CEA is a part of the CBA process, namely by comparing realistic/feasible alternative/ policy proposals (benefits exceed costs), to then determine which alternative has the highest benefit-cost ratio, seen from the outcome/results to be obtained. On the other hand, CBA has a relation with RIA because CBA is a part of the RIA process, namely conducting an analysis of the economic, social, environmental, health, security, and other impacts on stakeholders, such as the business world/manpower industry, consumers/ community, government and other stakeholders. An assessment of benefits and costs is a key component of the analysis in conducting RIA. Therefore, in analyzing the content materials of the laws and regulations under the law which are applied for review, it may be possible to use the RIA, CBA and CEA regulatory analysis models on the tested regulations to produce good regulations, because the three models are interrelated with one another. ${ }^{36}$

\footnotetext{
Ibid., 73 .

Ibid., 74 .

${ }^{36}$ Ibid., 75 .
}

\section{CONCLUSION}

The omnibus law model is a legal breakthrough in simplifying overlapping regulations. To simplify regulations under the law at the ministry/agency level, it is necessary to make a kind of omnibus law in the form of a joint regulation. Meanwhile, regulations at the regional level need to be simplified by combining various regional regulations that have similar substance in one regulation so that regulations at the central and regional levels are easier, simpler and do not overlap. The way of examining disharmony regulations in the concept of Draft Government Regulation on Harmonization and Synchronization of Laws and Regulations under the Law has weaknesses that are difficult to solve. First, the Working Group's examination according to the concept of Draft Government Regulation on Harmonization and Synchronization is a test of laws and regulations under the law, not including the revocation stage. This is not in accordance with the theory of judicial review. Second, the examination and testing carried out in accordance with the concept of Draft Government Regulation clearly contradicts the judicial review by the Supreme Court as regulated in Article 24 A of the 1945 Constitution, the Supreme Court Law, and the UUP3. Third, the concept of Draft Government Regulation does not have an examination method, trial procedures, trial time limit and legal remedies for parties who do not accept the decision. In addition, an ad hoc examination which is only based on an application to examine laws and regulations under the law is unable to comprehensively resolve disharmony regulations in responding to legal needs in order to improve the economy.

\section{SUGGESTION}

The concept of Draft Government Regulation on Harmonization and Synchronization needs to be revised and shall not use a semi-judicial model, but shall use an analysis and evaluation model (executive review) carried out by each ministry/agency and local government, which is coordinated by the National Law Development Agency. The analysis and evaluation activities shall be still carried out by a team. The revised concept of Draft Government Regulation shall be regulated using a methodological approach in conducting examination so that the results of 
analysis and evaluation activities can produce good regulations.

\section{ACKNOWLEDGEMENT}

This paper is an adaptation of the results of research conducted by the author and the team. In carrying out the research, the author received support from academicians. For that we would like to thank Prof. Dr. Ida Bagus Rahmadi Supancana as reviewer. We would also like to thank the source persons, including: Dr. Wicipto Setiadi, Dr. Fitriani Ahlan Sjarif, Dr. Bayu Dwi Anggoro and Jamin Ginting.

\section{BIBLIOGRAPHY}

Adhi Setyo Prabowo dkk. "Penerapan Omnibus Law Dalam Upaya Reformasi Regulasi.” Pamator 13 No. 1 (2020): 3.

Ahmad Redi \& Ibnu Sina Chandranegara. Omnibus Law, Diskursus Penerapannya Dalam Sistem Perundang Undangan Nasional. Depok: Rajawali Pers, 2020.

Antoni Putra. "Penerapan Omnibus Law Dalam Upaya Reformasi Regulasi.” LEGISLASI INDONESIA 17 No.1 (2020): 2.

Asshiddiqie, Jimly. Omnibus Law Dan Penerapannya Di Indonesia. Jakarta: Konstitusi Press, 2020.

Bayu Dwi Anggoro. Perkembangan Pembentukan Undang-Undang Di Indonesia. Edited by Rita Triana Budiarti. 1st ed. Jakarta: Konstitusi Press, 2014.

Budiyono, Tri. Transplantasi Hukum Harmonisasi Dan Potensi Benturan. Salatiga: Griya Media, 2009.

Dahlan Barry and Et.al. Kamus Modern Bahasa Indonesia. Jogyakarta: Arkola, 1995.

Fakultas Hukum Universitas Gadjah Mada. Kertas Kebijakan Catatan Kritis Terhadap UU No 11 Tahun 2020 Tentang Cipta Kerja, Edisi 2/ 5 November 2020, Diterbitkan Oleh : Fakultas Hukum Universitas Gadjah Mada Tahun 2020, Hlm. 4. Jogyakarta, 2020.

Goesniadhie, Kusnu. Harmonisasi Sistem Hukum : Mewujudkan Tata Pemerintahan Yang Baik. Malang: Nasa Media, 2010.
I Putu Eka Cakra dan Aditya Yuli Sulistyawan. "Kompabilitas Penerapan Konsep Omnibus Law Dalam Sistem Hukum Indonesia." Crepido 02 No.02 (2020): 60.

Ida Bagus Rahmadi Supancana. Sebuah Gagasan Tentang Grand Design Reformasi Regulasi Indonesia. Jakarta: Universitas Katolik Indonesia-Atma Jaya, 2017.

Kementerian Koordinator Bidang Perekonomian Republik Indonesia, Omnibus Law Cipta Lapangan Kerja. "OMNIBUS LAW CIPTA LAPANGAN KERJA,.” Https:// Dikti.Kemdikbud.Go.Id/Wp-Content/ Uploads/2020/10/Booklet-UU-Cipta-Kerja. Pdf.

Khairul Fahmi. Menggagas Arah Kebijakan Reformasi Regulasi Di Indonesia Prosiding Forum Akademik Kebijakan Reformasi Regulasi 2019. 1st ed. Jakarta: Yayasan Studi Hukum dan Kebijakan Indonesia (YSHK), 2019.

Mutaya Saroh. “Apa Itu Implementasi? Tujuan Dan Contoh Penerapannya." Suara.Com, n.d.

Peter Mahmud Marzuki. Penelitian Hukum. 7th ed. Jakarta: Kencana Prenada Media Group, 2011.

Redi, and Ahmad. Hukum Pembentukan Peraturan Perundang-Undangan. Jakarta: Sinar Grafika, 2018.

Satjipto Rahardjo. Ilmu Hukum. V. Bandung: Citra Aditya Bakti, 2000.

Satjipto Rahardjo, dkk. Refleksi Dan Rekonstruksi Ilmu Hukum Indonesia. Edited by Awaluddin Marwan Esmi Warassih, Suteki. 1st ed. Yogyakarta: Thafa Media, 2012.

Soerjono \& Mamuji Soekanto, Sri. Penelitian Hukum Normatif: Suatu Tinjauan Singkat. 5th ed. Jakarta: Raja Grafindo Persada, 2011.

Sukardi. Pengawasan Dan Pembatalan Peraturan Daerah. Edited by Ahmad Fikri Hadin. 1st ed. Bantul, Yogyakarta: Genta, 2016. 
HALAMAN KOSONG

472 Jurnal Penelitian Hukum De Jure Vol. 21 No. 4, December 2021: 459-472 